\section{Surgical excision of a giant soft fibroma of the labia majora covered with a pudendal artery perforator flap}

Jong Yun Choi, Jin Tae Cho, Bommie Florence Seo, Jangyoun Choi, Sung-No Jung

Department of Plastic and Reconstructive Surgery, College of Medicine, The Catholic University of Korea, Seoul, Korea

\author{
Correspondence: Sung-No Jung \\ Department of Plastic and Reconstructive Surgery, Uijeongbu St. Mary's \\ Hospital, College of Medicine, the Catholic University of Korea, 271 Cheonbo- \\ ro, Uijeongbu 11765 , Korea \\ Tel: +82-31-820-3935, Fax: +82-31-874-030 \\ E-mail:jsn7190@catholic.ac.kr
}

Received: October 29, $2019 \bullet$ Revised: November 7, 2019

- Accepted: November 7, 2019

pISSN: 2234-6163 • elSSN: 2234-6171

https://doi.org/10.5999/aps.2019.01599

Arch Plast Surg 2020;47:108-109

Copyright (C) 2020 The Korean Society of Plastic and Reconstructive Surgeons

This is an Open Access article distributed under the terms of the Creative Common

Attribution Non-Commercial License (https://creativecommons.org/licenses/by-nc/4.0/)

which permits unrestricted non-commercial use, distribution, and reproduction in any

medium, provided the original work is properly cited.

Tumors of the vulva are very rare, and only a few cases have been reported. Soft fibroma is the most common benign tumor of the genital area; it is a benign proliferation that has multiple forms and is usually less than $5 \mathrm{~cm}$ in size [1]. It frequently occurs on the torso or face, in locations such as the eyelids, neck, or axilla, and is rarely found on the vulva [2]. Initially, the tumor is often asymptomatic, but soft fibromas on the vulva can cause extreme social withdrawal, urinary symptoms, and bleeding due to ulceration after years of growth. Vulvar tumors are usually treated by surgical excision and, unless confirmed to be malignant, they typically do not present complications [3]. A 32-year-old nulliparous patient presented to the gynecology department as an outpatient with a painless, soft-to-firm, pedunculated mass on the labia majora. The tumor measured $60 \mathrm{~cm}$ in length, $50 \mathrm{~cm}$ in width, and $15 \mathrm{~cm}$ in thickness, and contained an ulcerative skin defect $4 \mathrm{~cm}$ in diameter. The mass had been progressively growing over the past 15 years (Fig. 1). A general and speculum examination revealed no other abnormalities. The patient underwent total excision of the mass from the stalk encircling the base of the attachment and a coverage operation with a musculocutaneous flap using internal pudendal artery perforators under general anesthesia (Fig. 2). A histopathological examination showed fibrous tissue without atypia, consistent with soft fibroma (Fig. 3). The patient was discharged 2 weeks after surgery without

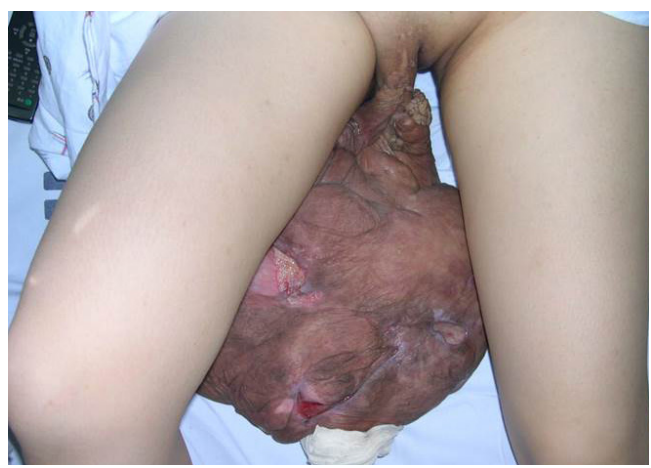

Fig. 1.

Clinical photograph of a huge mass on the patient's labia majora. The tumor measured $60 \mathrm{~cm}$ in length, 50 $\mathrm{cm}$ in width, and $15 \mathrm{~cm}$ in thickness, with an ulcerative skin defect $4 \mathrm{~cm}$ in a diameter.

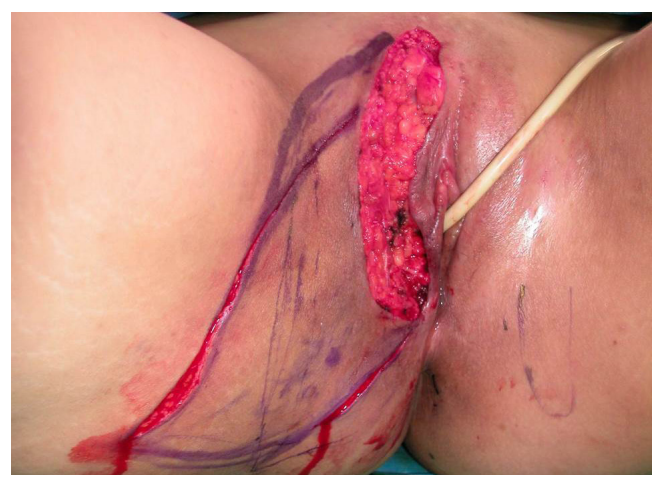

Fig. 2.

Intraoperative clinical photograph of the

musculocutaneous flap. A musculocutaneous flap using internal pudendal artery perforators was designed after total excision of the giant soft fibroma.

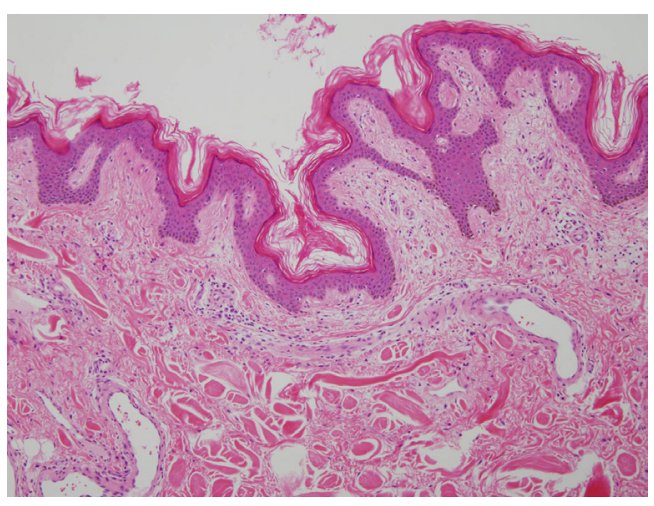

Fig. 3.

Histopathological examination. Hyperplastic epidermidis with hyperkeratosis and acanthotic features consistent with soft fibroma $(H \& E, \times 100)$. 


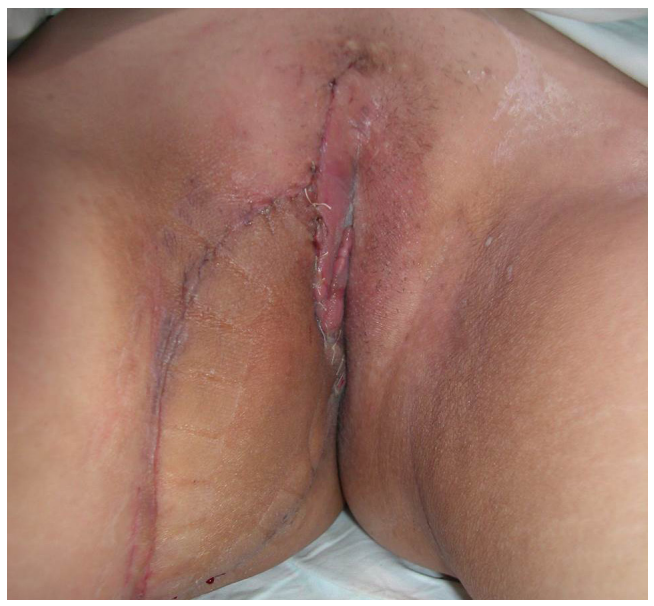

complications. During the follow-up period, no additional complications were encountered (Fig. 4).

\section{Notes}

\section{Conflict of interest}

No potential conflict of interest relevant to this article was reported.

Ethical approval

The study was performed in accordance with the principles of the Declaration of Helsinki. Written informed consent was obtained.

\section{Patient consent}

The patient provided written informed consent for the publication and the use of her images.

\section{Author contribution}

Conceptualization, methodology: Jung SN. Methodology and visualization: Seo BF. Project administration: Choi JY. Data curation, writingoriginal draft: Cho JT. Writing-review \& editing: Choi J, Choi JY.
Fig. 4.

Clinical photograph of the wound postoperatively. The patient was discharged without any complications, and no additional complications were encountered during 12 months of follow-up.

\section{ORCID}

Jong Yun Choi https://orcid.org/0000-0002-11644499

Jin Tae Cho https://orcid.org/0000-0001-7052-

9418

Bommie Florence Seo https://orcid.org/0000-

0002-6907-5962

Jangyoun Choi https://orcid.org/0000-0002-51658414

Sung-No Jung https://orcid.org/0000-0002-04194717

\section{References}

1. Kurman RJ, Ellenson LH, Ronnett BM. Blaustein's pathology of the female genital tract. 6th ed. New York: Springer; 2011.

2. Lopes Filho LL, Lopes IMRS, Ferreira Filho ES, et al. Giant soft fibroma located in the vulva: a case report. Surg Cosmet Dermatol 2012;4:200-2.

3. Haley JC, Mirowski GW, Hood AF. Benign vulvar tumors. Semin Cutan Med Surg 1998;17:196-204. 